\title{
Characterization of pancreatic ductal cells in human islet preparations
}

\author{
Hirohito Ichii ${ }^{1,2,3}$, Atsushi Miki ${ }^{1}$, Toshiyuki Yamamoto ${ }^{1}$, Ruth D Molano ${ }^{1}$, Scott Barker ${ }^{1}$, Atsuyoshi Mita ${ }^{1}$, \\ Rayner Rodriguez-Diaz ${ }^{1}$, Dagmar Klein ${ }^{1}$, Ricardo Pastori ${ }^{1}$, Rodolfo Alejandro ${ }^{1,4}$, Luca Inverardi ${ }^{1,5}$, \\ Antonello Pileggi, ${ }^{1,2}$ and Camillo Ricordi ${ }^{1,2,3,4,5}$
}

Substantial amounts of nonendocrine cells are implanted as part of human islet grafts, and a possible influence of nonendocrine cells on clinical islet transplantation outcome has been postulated. There are currently no product release criteria specific for nonendocrine cells due to lack of available methods. The aims of this study were to develop a method for the evaluation of pancreatic ductal cells (PDCs) for clinical islet transplantation and to characterize them regarding phenotype, viability, and function. We assessed 161 human islet preparations using laser scanning cytometry (LSC/iCys) for phenotypic analysis of nonendocrine cells and flow cytometry (FACS) for PDC viability. PDC and $\beta$-cells obtained from different density fractions during the islet cell purification were compared in terms of viability. Furthermore, we examined PDC ability to produce proinflammatory cytokines/chemokines, vascular endothelial growth factor (VEGF) and tissue factor (TF) relevant to islet graft outcome. Phenotypic analysis by LSC/iCys indicated that single staining for CK19 or CA199 was not enough for identifying PDCs, and that double staining for amylase and CK19 or CA19-9 allowed for quantitative evaluation of acinar cells and PDC content in human islet preparation. PDC showed a significantly higher viability than $\beta$-cells (PDC vs $\beta$-cell: $75.5 \pm 13.9$ and $62.7 \pm 18.7 \% ; P<0.0001$ ). Although $\beta$-cell viability was independent of its density, that of PDCs was higher as the density from which they were recovered increased. There was no correlation between PDCs and $\beta$-cell viability $\left(R^{2}=0.0078\right)$. PDCs sorted from high-density fractions produced significantly higher amounts of proinflammatory mediators and VEGF, but not TF. We conclude that PDCs isolated from different fractions had different viability and functions. The precise characterization and assessment of these cells in addition to $\beta$-cells in human islet cell products may be of assistance in understanding their contribution to islet engraftment and in developing strategies to enhance islet graft function.

Laboratory Investigation (2008) 88, 1167-1177; doi:10.1038/labinvest.2008.87; published online 8 September 2008

KEYWORDS: pancreatic ductal cells; islet transplantation; cytokines; laser scanning cytometer; VEGF; CA19-9

Clinical islet transplantation results in insulin independence and normalization of glycemic control in patients with type 1 diabetes mellitus. ${ }^{1-4}$ Current limitations of this approach include survival of transplanted islets, which eventually leads to reintroduction of exogenous insulin. ${ }^{4-6}$ Reduction or impairment of islet regeneration might potentially contribute to the observed loss of function over time in islet graft recipients. This phenomenon may be associated with adverse effects of immunosuppressive drugs, the unsuitable implantation site (liver) for islet regeneration, and/or loss of $\beta$-cell precursors in the transplanted islet preparations. ${ }^{7-9}$

Pancreatic ductal cells (PDCs) have been shown to differentiate into insulin-producing cells in rodents and humans. ${ }^{10-13}$ PDC can improve islet survival ${ }^{14}$ and engraftment in rodents, which was associated with their ability of producing insulin growth factor II (IGF-II). ${ }^{15}$ Moreover, Korbutt et al have reported a positive correlation between the proportion of transplanted PDC and the long-term

\footnotetext{
${ }^{1}$ Cell Transplant Center, Diabetes Research Institute, University of Miami Leonard M. Miller School of Medicine, Miami, FL, USA; ${ }^{2}$ DeWitt-Daughtry Family Department of Surgery, University of Miami Leonard M. Miller School of Medicine, Miami, FL, USA; ${ }^{3}$ Transplant Institute, University of Miami Leonard M. Miller School of Medicine, Miami, FL, USA; ${ }^{4}$ Department of Medicine, University of Miami Leonard M. Miller School of Medicine, Miami, FL, USA and ${ }^{5}$ Department of Microbiology and Immunology, University of Miami Leonard M. Miller School of Medicine, Miami, FL, USA

Correspondence: Professor H Ichii, MD, PhD, Cell Transplant Center, Diabetes Research Institute, University of Miami Leonard M. Miller School of Medicine, 1450 NW 10th Avenue (R-134) Miami, FL 33136, USA.

E-mail: hichii@med.miami.edu

Received 25 June 2008; accepted 29 June 2008
} 
metabolic success of clinical islet transplantation. ${ }^{16}$ Additionally, Pipeleers et al have recently shown that PDC could produce higher amounts of interleukin-8 (IL-8) and vascular endothelial growth factor (VEGF) than islet cells, which could be helpful for revascularization in islet grafts. ${ }^{17}$ Conversely, PDC express tissue factor (TF) and cytokines/ chemokines that may be detrimental to islet engraftment. ${ }^{18,19}$ Thus, the contribution of PDC to islet graft needs to be better characterized.

Current release criteria for human islet cell products include islet purity and yield based on dithizone (DTZ) staining, ${ }^{20}$ which provides an estimate of endocrine cell mass in the preparation. The actual purity of islet preparations transplanted into patients averages $50-60 \%$, indicating that a substantial mass of nonendocrine cells, mainly acinar cells and PDC, are also implanted. Notably, the current productrelease criteria do not take into account nonendocrine cell quality and quantity, even though emerging data suggest their possible influence on clinical islet transplantation outcome. ${ }^{16}$ In addition, there is no reliable method available to evaluate PDC in the islet cell product. Consequently, only few transplant centers have performed pretransplant evaluation of PDC and no data are available regarding the effect of transplanted PDC on islet grafts.

In this study, we developed a novel method to evaluate PDC-specific viability and content based on the use of laser scanning cytometry (LSC/iCys) and flow cytometry (FACS). This assay extends and complements our previously reported method for the assessment of $\beta$-cell-specific viability and content in islet preparations. ${ }^{20}$ This method allows for the evaluation of cell-subset-specific viability (PDC and $\beta$-cells) simultaneously as well as for the detailed phenotypic analysis of PDC and acinar cells. We investigated PDC phenotype, viability and function in 161 human islet preparations. PDC content widely varied among islet preparations even though they had similar purity. PDC isolated from different density fractions showed wide variations in the viability and the production of proinflammatory cytokine/chemokine, VEGF and TF, which are relevant to islet transplantation outcomes.

\section{MATERIALS AND METHODS Human Islet Isolation}

Islet isolations were performed using a modified automated method from pancreata preserved with University of Wisconsin solution alone or with preoxygenated two-layer perfluorocarbon at the Human Cell Processing Facility of the University of Miami School of Medicine. ${ }^{21,22}$

Islets were purified using a semi-automated cell processor (Cobe 2991; COBE Laboratories Inc., Lakewood, CO, USA) in a refrigerated $\left(4^{\circ} \mathrm{C}\right)$ room. The purification procedure consisted of a continuous gradient purification performed by loading $1.100 \mathrm{~g} / \mathrm{ml}$ (osmolality $320-373 \mathrm{mOsm} / \mathrm{kg} / \mathrm{H}_{2} \mathrm{O}$ ) and $1.077 \mathrm{~g} / \mathrm{ml} \quad\left(285-327 \mathrm{mOsm} / \mathrm{kg} / \mathrm{H}_{2} \mathrm{O}\right)$ Ficoll-based density gradients using a gradient maker device, followed by toploading of the pancreatic digest ( $\leq 20 \mathrm{ml}$ of tissue/run) in
UW solution. ${ }^{23}$ After 5 min of centrifugation at 2400 r.p.m., approximately 15 fractions were collected. Islet fractions were combined based on the purity assessed by DTZ. In general, the fractions with highest islet purity were collected from the low-density fractions $4-7$ (density 1.081-1.085 g/ml). Medium and high-density islet fractions were combined with fractions $8-10$ and $11-14$ (1.86-1.090 and $1.091-1.095 \mathrm{~g} / \mathrm{ml}$, respectively).

\section{Assessment of PDC Content Using LSC/iCys}

Assessments of PDC content and viability were performed 48-72 h after isolation. Single cell suspensions were obtained by incubating aliquots of approximately 2000 islet equivalents (IEQ) in $1 \mathrm{ml}$ Accutase (Innovative Cell Technologies Inc., San Diego, CA, USA) at $37^{\circ} \mathrm{C}$ for $10 \mathrm{~min}$, as described. ${ }^{24}$ Dispersed cells were fixed on glass slides with $2.5 \%$ paraformaldehyde (Electron Microscopy Sciences, Washington, PA, USA). After incubating with Protein Block (Bio-Genex, San Ramon, CA, USA), cells underwent $2 \mathrm{~h}$ incubation with primary antibodies: mouse monoclonal anti-cytokeratin (CK)-19 (1:50; Dako North America Inc., Carpinteria, CA, USA); rabbit polyclonal anti-CK19 (KRT19; 1:200; Protein Tech Group Inc., Chicago, IL, USA); mouse monoclonal anti-CA19-9 (1:100; Novocastra, UK) and rabbit polyclonal anti-amylase (1:5000; Amy; Dako). A $1 \mathrm{~h}$ incubation with secondary antibodies included Alexa Fluor-488 goat antimouse IgG and Alexa Fluor-647 goat anti-rabbit IgG (1:200; Molecular Probes, Eugene, OR, USA). Nuclear staining was obtained with $4^{\prime}, 6$-diamidino-2-phenylindole (DAPI; $16.7 \mu \mathrm{g} / \mathrm{ml}$; Molecular Probes). Samples were analyzed using a LSC/iCys (CompuCyte, Cambrige, MALSC). Slides were scanned at $\times 40$. Each fluorescent positive event was recorded using the argon/HeNe/violet laser. Single cells were identified and gated according to the DAPI staining area (Figure 1a). Cells from every subpopulation were visualized directly in the LSC/iCys by relocalization to confirm regular morphology (Figure 1c). A minimum of 5000 cells was acquired and analyzed for each sample. ${ }^{20}$

\section{Assessment of PDC-Specific Viability}

Single cell suspensions were incubated for $30 \mathrm{~min}$ at $37^{\circ} \mathrm{C}$ in phosphate-buffered saline without $\mathrm{Ca}^{2+}$ and $\mathrm{Mg}^{2+}$ with Newport Green PDX acetoxymethylether (NG; $1 \mu \mathrm{M})$ and tetramethylrhodamineethylester (TMRE; $100 \mathrm{ng} / \mathrm{ml}$; both from Molecular Probes). Cells were incubated with anti-CA19-9 antibody (1:100) for $15 \mathrm{~min}$ followed by goat anti-mouse antibody (Alexa-647). After washing, cells were stained with 7-aminoactinomycin D (7-AAD; Molecular Probes), a marker of cell death. Cell suspensions were analyzed (minimum $3.0 \times 10^{4}$ events) using a FACScan cytometer with the CellQuest-pro software (Becton Dickinson, Mountain View, CA, USA). We have evaluated apoptosis selectively in the $\mathrm{NG}^{\text {bright }}$ and CA19-9 ${ }^{+}$cells according to the scheme in Figure 3. After counting, dead cells $\left(7-\mathrm{AAD}^{+}\right)$ were excluded from further analysis, live $\beta$-cells $\left(\mathrm{NG}^{\text {bright }}\right.$ ) 

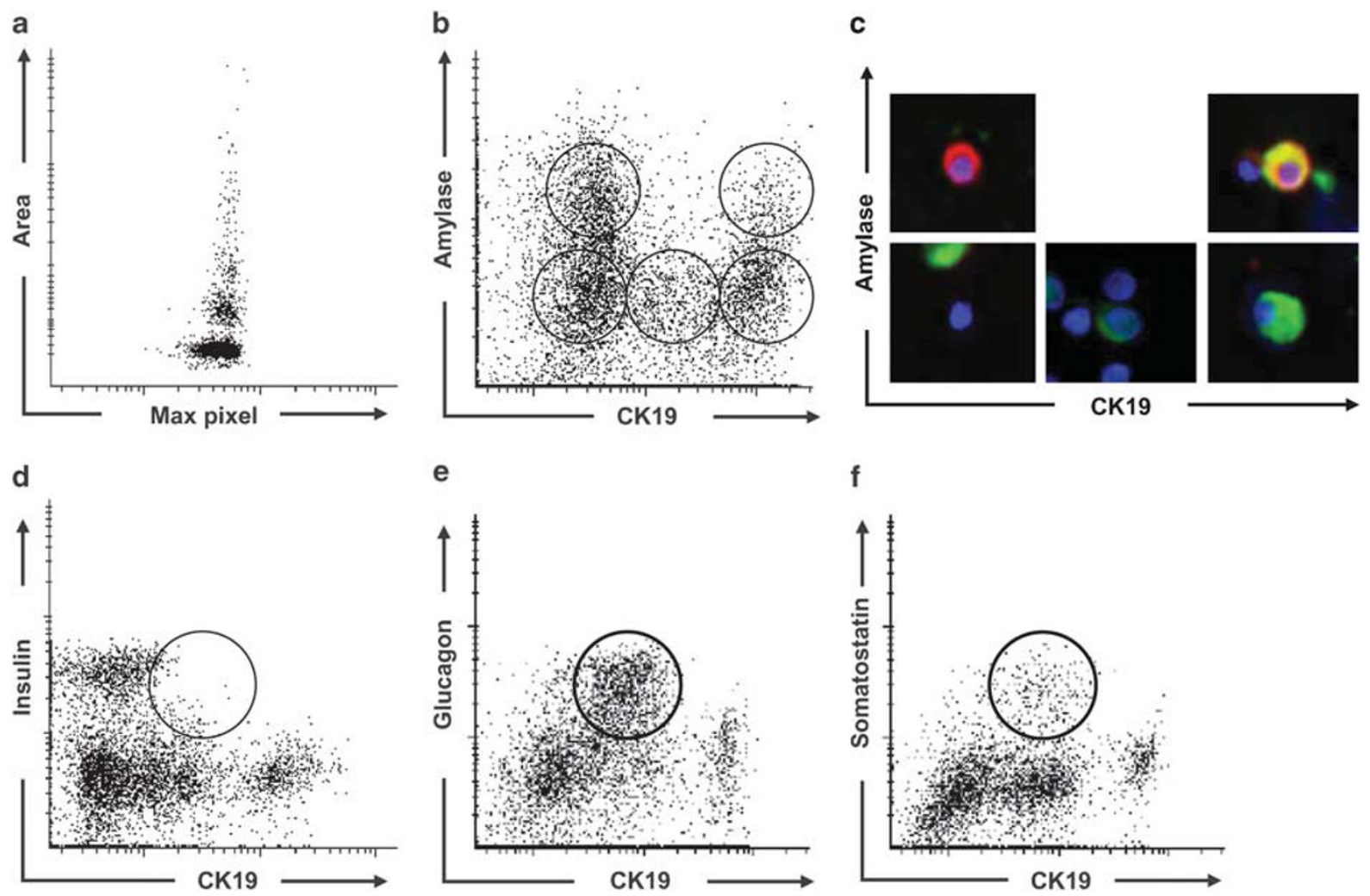

Figure 1 Phenotypic analysis of PDC in human islet preparations by LSC/iCys. An aliquot of islet preparations was dissociated to obtain single-cell suspensions. Fixed cells were stained with anti-CK19, amylase, glucagon, somatostatin, and insulin antibodies. The appropriate fluorochrome-conjugated secondary antibody was subsequently added. (a) Single cells were identified based on DAPI fluorescence emission area, whereas aggregated cells were excluded from further analysis. (b) The LSC/iCys analysis of the double staining with CK19 and amylase revealed five cell subsets based on the intensity of fluorescence. (c) Cells from every subpopulation were directly visualized by relocalization system in the LSC/iCys to confirm regular morphology. Double staining with anti-CK19 was performed to identify the cell population with the phenotype of CK19 ${ }^{\text {dull }}$ and Amylase ${ }^{-}$. The results showed CK19dull expression was absent in $\beta$-cells (d) but present in $\alpha$-cells (e) and $\delta$-cells (f). The experiments shown are representative of five independent human islet preparations.

and PDC $\left(\mathrm{CA} 19-9^{+}\right)$were analyzed for mitochondrial membrane potential (TMRE), which allows discriminating between healthy $\left(\mathrm{TMRE}^{+}\right)$and apoptotic $\left(\mathrm{TMRE}^{-}\right)$cells. The percentage of $\mathrm{TMRE}^{+}$on each cell subset was decided based on the gate of TMRE unstained samples.

\section{Delivery of Proapoptotic Stimuli to Islet and Nonendocrine Cells}

Islets were treated with selected compounds for $24 \mathrm{~h}$ to induce apoptosis, as described, ${ }^{25}$ including the nitric oxide (NO) donor, $S$-Nitroso- $N$-acetyl-DL-penicillamine $(0.5 \mathrm{mM}$; Sigma, St Louis, MO, USA); hydrogen peroxide $\left(\mathrm{H}_{2} \mathrm{O}_{2}\right.$ $200 \mu \mathrm{M}$; Sigma); or cytokine cocktail with IL-1- $\beta(50 \mathrm{U} / \mathrm{ml})$, TNF- $\alpha(1,000 \mathrm{U} / \mathrm{ml})$ and IFN $-\gamma(1000 \mathrm{U} / \mathrm{ml})$. Hypoxic stress was induced by a $6-\mathrm{h}$ incubation of islet aliquots as a pellet into a $15 \mathrm{ml}$ conical tube filled with culture medium. ${ }^{20}$

\section{PDC Sorting}

Dispersed cells were incubated with anti-CA19-9 antibody for $30 \mathrm{~min}$ followed by a $10 \mathrm{~min}$ incubation with magnetic beads coated with an anti-mouse IgG (Miltenyi Biotec,
Auburn, CA, USA). The cell suspension was passed through a MACS separation column (Miltenyi Biotec) to obtain positive selection of CA19-9 ${ }^{+}$cells. The efficiency of sorting was confirmed by FACS analysis. ${ }^{26}$

Production of Inflammatory Mediators and VEGF by PDC During islet purification by density gradients, pancreatic tissue fractions with different densities (low $=1.080-1.085$, medium $=1.086-1.090$, high $=1.091-1.095 \mathrm{~g} / \mathrm{ml})$ were collected. PDC were sorted from high- and low-density fractions obtained from five independent islet preparations. Enriched PDC $\left(1 \times 10^{6}\right.$ per ml $)$ were cultured for $24 \mathrm{~h}^{27}$ Concentrations of proinflammatory mediators (namely, IL-1- $\beta$, IL-6, IL-8, IFN- $\gamma$, MCP-1, MIP-1 $\beta$ and TNF- $\alpha$ ) and VEGF in supernatants were determined using Multi-Plex cytokine kits following the manufacturer's protocol (Bio-Plex; Bio-Rad Laboratories, Hercules, CA, USA). Additionally, PDC were homogenized, and TF measured by ELISA (Imubind Tissue Factor; American Diagnostica, Greenwich, CT, USA). ${ }^{25}$ The amount of cytokines/chemokines, VEGF and TF was normalized by total PDC protein content. 


\section{In Vitro Viability Assessment of Islet Preparations Cultured with Or Without PDC}

Islet preparations (3000 IEQ, purity $>95 \%$ ) were cultured with or without sorted PDC for $48 \mathrm{~h}$. The assessment of $\beta$-cell-specific viability was performed as described. ${ }^{24}$

\section{In Vivo Assessment of Islet Potency in the Diabetic Nude Mouse Model}

Animal protocols were approved by IACUC. Athymic nu/nu mice (Harlan Laboratories, Indianapolis, IN, USA) were rendered diabetic with Streptozotocin $(200 \mathrm{mg} / \mathrm{kg}$, single intravenous administration; Sigma). Diabetes occurrence (>300 mg/100 ml) was monitored by measurements of nonfasting blood glucose concentrations.

Human islets (2000 and 1000 IEQ, purity >95\%) alone or with sorted PDC $\left(3 \times 10^{6}\right)$ were transplanted under the kidney capsule of diabetic immunodeficient mice as described. ${ }^{22}$ After transplantation, nonfasting blood glucose values were assessed to determine reversal of diabetes (defined as stable nonfasting blood glucose $<200 \mathrm{mg} / 100 \mathrm{ml}$ ). Nephrectomy of the graft-bearing kidney was performed to exclude residual function of the native pancreas. ${ }^{22}$

\section{Statistical Analysis}

Data were analyzed using Excel for Windows software. Data are shown as mean \pm s.e.m. Statistical analyses were preformed using methods appropriate to each specific analysis including Student's $t$-tests for two sample comparisons of independent groups, and two-factor analysis of variance (ANOVA) for analyses of ductal and $\beta$-cell viability from different density fractions. Statistical significance was considered for $P$-values $<0.05$. Logistic regression was then used to explore the influence of the two factors separately.

\section{RESULTS}

\section{Phenotpic Analysis of Nonendocrine Cells in Islet Prepatrations Using LSC/iCys}

To assess the proportion of nonendocrine cells in islet preparations, Amy and CK19 were used for the identification of acinar cells and PDC, respectively. This led to the identification of five cell subpopulations $\left(\mathrm{Amy}^{-} \mathrm{CK} 19^{\text {negative }}, \mathrm{Amy}^{+} \mathrm{CK} 19^{\text {negative }}\right.$, $\mathrm{Amy}^{-} \mathrm{CK} 19^{\text {dull }}, \mathrm{Amy}^{+} \mathrm{CK} 19^{\text {bright }}$, Amy ${ }^{-} \mathrm{CK} 19^{\text {bright }}$; Figure 1b). Although LSC/iCys analysis clearly showed $\mathrm{Amy}^{+}$ CK19 ${ }^{\text {negative }}$ cells indicating exocrine cells, another cell subset Amy ${ }^{+} \mathrm{CK} 19^{\text {bright }}$ was also identified in most of human islet preparations.

In order to characterize this $\mathrm{Amy}^{-} \mathrm{CK} 19^{\text {dull }}$ population, immunostaining for insulin, glucagon and somatostatin was combined with CK19. The LSC/iCys analysis revealed that $\alpha$-cells and $\delta$-cells, but not $\beta$-cells, do express CK19 dull (Figure 1d-f). The proportion of $\beta-, \alpha-, \delta$-, Amy ${ }^{+}$ CK19 ${ }^{\text {negative }}$; Amy ${ }^{-} \mathrm{CK} 19^{\text {bright }}$ and $\mathrm{Amy}^{+} \mathrm{CK} 19^{\text {bright }}$ cells from 106 islet preparations were $21.1 \pm 8.7,19.1 \pm 8.4,3.8 \pm 2.1$, $10.4 \pm 8.1, \quad 10.4 \pm 8.2$ and $6.4 \pm 3.2 \%$, respectively. These results indicate that single staining for CK19 is not specific for evaluating PDC content in islet preparations, and that LSC/iCys analysis allows for detailed phenotypic analysis of endocrine and nonendocrine cell subsets.

CK19 is an intracellular protein and, therefore, fixation of cells is necessary for its detection by immunostaining precluding its application on live cells. The carbohydrate antigen 19-9 (CA19-9) has been described as a pan-ductal membrane antibody for human PDC. ${ }^{26}$ Therefore, we evaluated the expression of $\mathrm{CK} 19^{\text {bright }}$ cells in 34 islet preparations and compared it to that of CA19-9 using LSC/iCys. A positive correlation between $\mathrm{CK} 19^{\text {bright }}$ and CA19-9 $9^{+}$expression was observed $\left(R^{2}=0.8752, p=0.032\right.$; Figure $\left.2 \mathrm{a}\right)$. Moreover, $\alpha$-cells and $\delta$-cells expressing CK19 ${ }^{\text {dull }}$ resulted negative to CA19-9, whereas a fraction of CA19-9 ${ }^{+}$cells expressed amylase (Figure $2 \mathrm{~b}-\mathrm{d}$ ).

These results suggest that CA19-9 is a better maker for identifying PDC than CK19 in terms of excluding the contamination of $\alpha$ and $\delta$ cells from the analysis without double staining, and that even the single staining of CA19-9 could not exclude the double positive cells with amylase from the analysis for the identification of PDC.

We examined 203 purified fractions from 106 human islet preparations with different purities assessed by DTZ and compared this to PDC content by CA19-9 immunostaining. Although PDC content and purity by DTZ showed a rough correlation $\left(R^{2}=0.4574\right)$, the proportion of CA19-9 ${ }^{+}$cells in islet preparations widely varied even if they had similar purity assessed by DTZ (Figure 3). This variability might be due to the different ratio of acinar and ductal cells contained in the DTZ negative population. These results indicate that it might be difficult to evaluate PDC content by DTZ staining, whereas FACS analysis by CA19-9 antibody allowed us to precisely assess PDC content in islet preparations.

\section{Analysis of PDC Viability Using CA19-9 and TMRE Staining}

We have developed an analytical method to simultaneously assess the viability of PDC and $\beta$-cells as well as the content of both cells by FACS (Figure 4). Viable (nonapoptotic) $\beta$-cells and PDC were analyzed for mitochondrial membrane potential by TMRE.

To confirm the value of our refined PDC and $\beta$-cell viability assessment method, we evaluated the effects of hypoxic/ starving conditions, reactive oxygen species (ROS), NO and cytokine cocktail (IL- $1 \beta$, TNF- $\alpha$ and IFN- $\gamma$; Figure $5 \mathrm{a}-\mathrm{d}$ ). All these noxious conditions led to a measurable decrease in the proportion of viable PDC and $\beta$-cells. Moreover, we observed that PDC are more resistant than $\beta$-cells to noxious conditions (Figure 5). In this setting, the percentages of $\mathrm{NG}^{\text {bright }}$ cells were not significantly different between pre and post treatments. The percentage of $\mathrm{NG}^{\text {bright }}$ cells in pretreatment, after hypoxic/starving conditions, $\mathrm{H}_{2} \mathrm{O}_{2}$, NO and cytokine cocktail treatment were $32.7 \pm 4.2,30.8 \pm 6.1,33.6 \pm 7.3$, $32.7 \pm 7.1$ and $30.0 \pm 5.3 \%$, respectively; $P=$ n.s. 

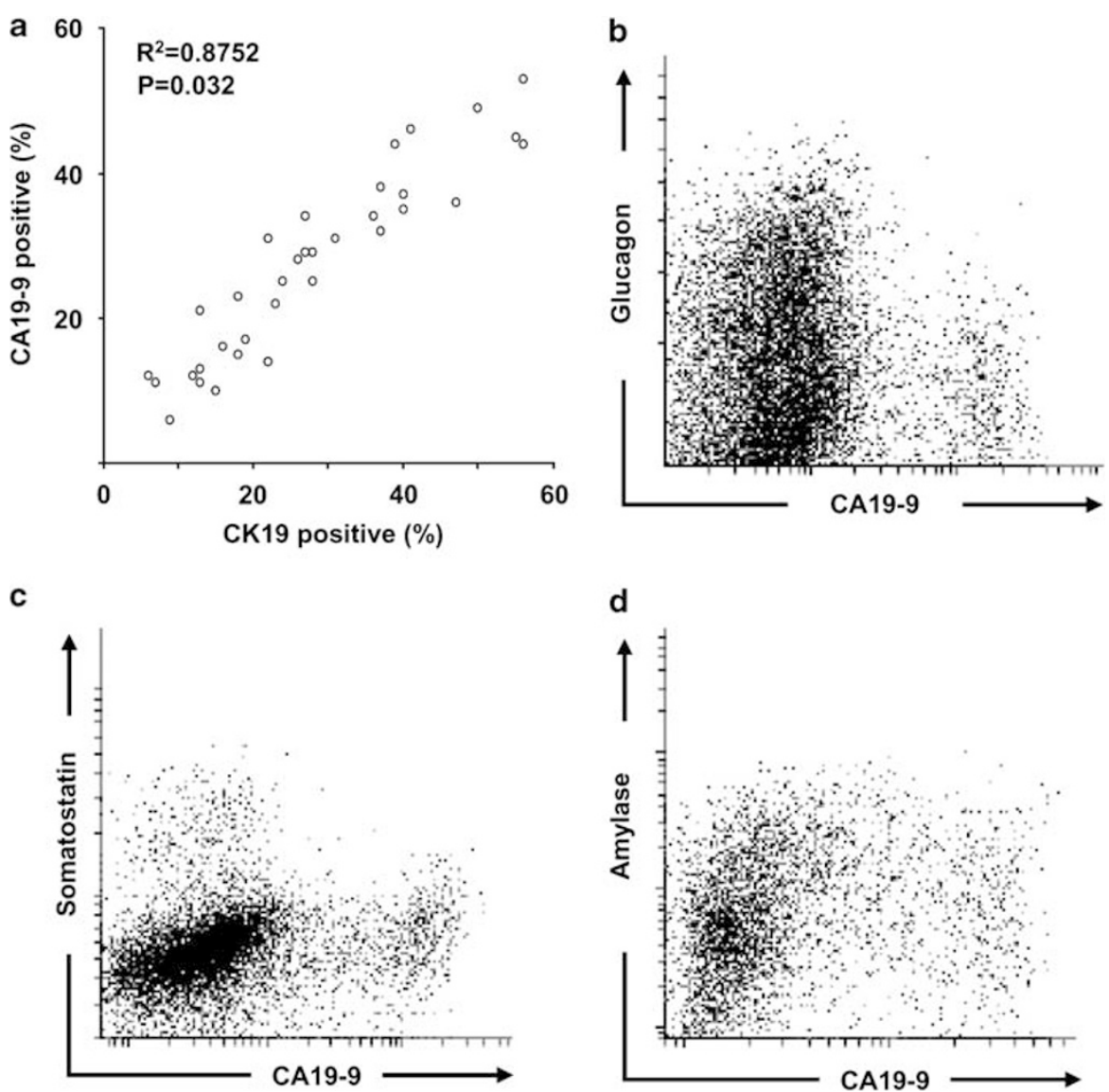

Figure 2 Analysis of CA19-9 expression in human islet preparations. The expression of CA19-9, the pan-ductal membrane antibody, was compared to that of CK19 using LSC/iCys. (a) There was a tight correlation observed between the percentage of CK19 ${ }^{\text {high }}$ and CA19-9 ${ }^{+}$populations ( $n=34$ ). (b-d) To confirm the specificity of CA19-9 antibody in PDC, double staining with anti-glucagon, somatostatin, and amylase antibodies was performed. The results showed CA19-9 expression was absent in $\alpha$-cells (b) and $\delta$-cells (c) but present in some acinar cells (d). The data shown are representative of five independent human islet preparations.

\section{Analysis of PDC Viability with Different Degrees of Purity}

We examined PDC and $\beta$-cell viability in 202 fractions from 124 human islet preparations. The average PDC viability was higher than that of $\beta$-cells (PDC $v s \beta$-cell: $75.5 \pm 13.9$ and $62.7 \pm 18.7 \%$, respectively; $P<0.0001)$. There was no correlation between PDC and $\beta$-cell viability $\left(R^{2}=0.0078\right.$; Figure 6a). These results suggested that the assay of heterogeneous cell populations such as FDA/PI, which has been currently used for clinical islet transplantation, could not represent $\beta$-cell-specific viability.

We selected 31 islet preparations, which had different purity fractions from three different density layers $($ low $=1.080-1.085, \quad$ medium $=1.086-1.090$ and high $=$ $1.091-1.095 \mathrm{~g} / \mathrm{ml}$ ) for analysis. The islet purity for each density fraction range: $95-71 \%$ (high), 70-41 (medium) and $40-10 \%$ (low), respectively. PDC and $\beta$-cell viability in each fraction was analyzed by FACS (Figure $6 \mathrm{~b}$ ). The relative ratio of PDC and $\beta$-cell viability within medium- and high-density fractions was calculated in regards to that obtained in the low-density fraction. The highest PDC viability was observed in fractions obtained from high-density, and decreased in those from low-density (medium/low $=1.15 \pm 0.33, P<0.05$; high/low $=1.31 \pm 0.53, P<0.05$; Figure $6 \mathrm{c}$ ). However, the analysis of $\beta$-cells showed that the relative viability in medium-density fractions was significantly higher, when compared to that of low- and high-density fractions $(P<0.05$, $P<0.01$, respectively) (Figure 6c). The islet sizes from each density layer were estimated using total IEQ/islet number and compared. Islet sizes from each gradient layer were comparable (high:medium:low $=1.34 \pm$ 0.57:1.38 \pm 1.02:1.51 $\pm 0.92, P=$ n.s.).

\section{Cytokines/Chemokines, VEGF and TF Production from CA19-9 ${ }^{+}$Cells}

To evaluate the function of PDC from different density fractions after purification, we sorted PDC using CA19-9 antibody. Sorted PDC were incubated in culture medium for $24 \mathrm{~h}$ and then supernatant was collected for the measurement of inflammatory mediators. Recovered cells were homogenized for the measurement of TF, which has been shown to be relevant to clinical outcomes. ${ }^{28,29}$ Cytokine and chemokine production from PDC isolated from high-density 
fractions was higher, when compared to that of low-density fractions. Moreover, PDC isolated from high-density fractions produced significantly higher amounts of VEGF, which could be beneficial for revascularization after transplantation. The data suggest that PDC with higher viability can produce larger amounts of proinflammatory mediators and VEGF

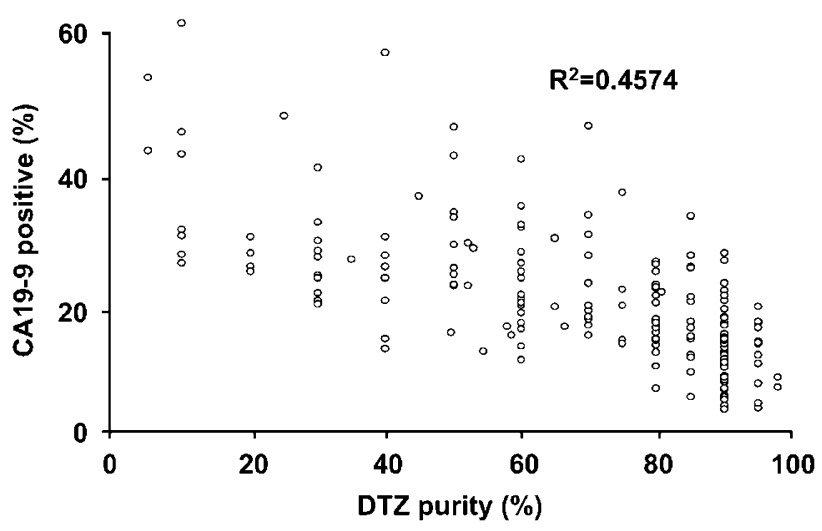

Figure 3 Analysis of CA19-9 expression in PDCs revealed the variability in individual human islet preparations. Analyses of 203 fractions from 106 independent human islet preparations were examined to evaluate PDC content using anti-CA19-9 antibody on dissociated cells by FACS. A negative correlation between the percentage of $\mathrm{CA} 19-9^{+}$and islet purity assessed by DTZ was observed.
(Figure 7a, Table 1). On the other hand, although impure islet preparations from high-density layers produced higher amount of TF, a significant reduction in TF production was observed from PDC obtained from high-density fractions (Figure $7 \mathrm{~b}$ and $\mathrm{c}$ ). These results suggested that the proportion and viability of PDC in islet preparations might be considered as one of the important factors that could affect islet graft function.

\section{Effects of PDC on Islet Potency}

To evaluate the effect of PDC on islet potency in vitro, sorted PDC were cultured with pure islet preparations for $48 \mathrm{~h}$ $(n=3)$. $\beta$-Cell-specific viability by FACS showed no significant difference in islets cultured with or without PDC ( $40.5 \pm 2.7,37.5 \pm 1.8 \%, P=$ n.s, respectively).

Additionally, using chemically induced diabetic immunodeficient mice we performed transplantation of islets with or without PDC for three independent human islet preparations (Figure 8). There was no significant difference between experimental groups regarding the rate of and the time to diabetes reversal after transplantation in both islet masses utilized.

\section{DISCUSSION}

In this study, we demonstrated that the use of three different dyes (7-AAD, NG and TMRE) and one surface antibody

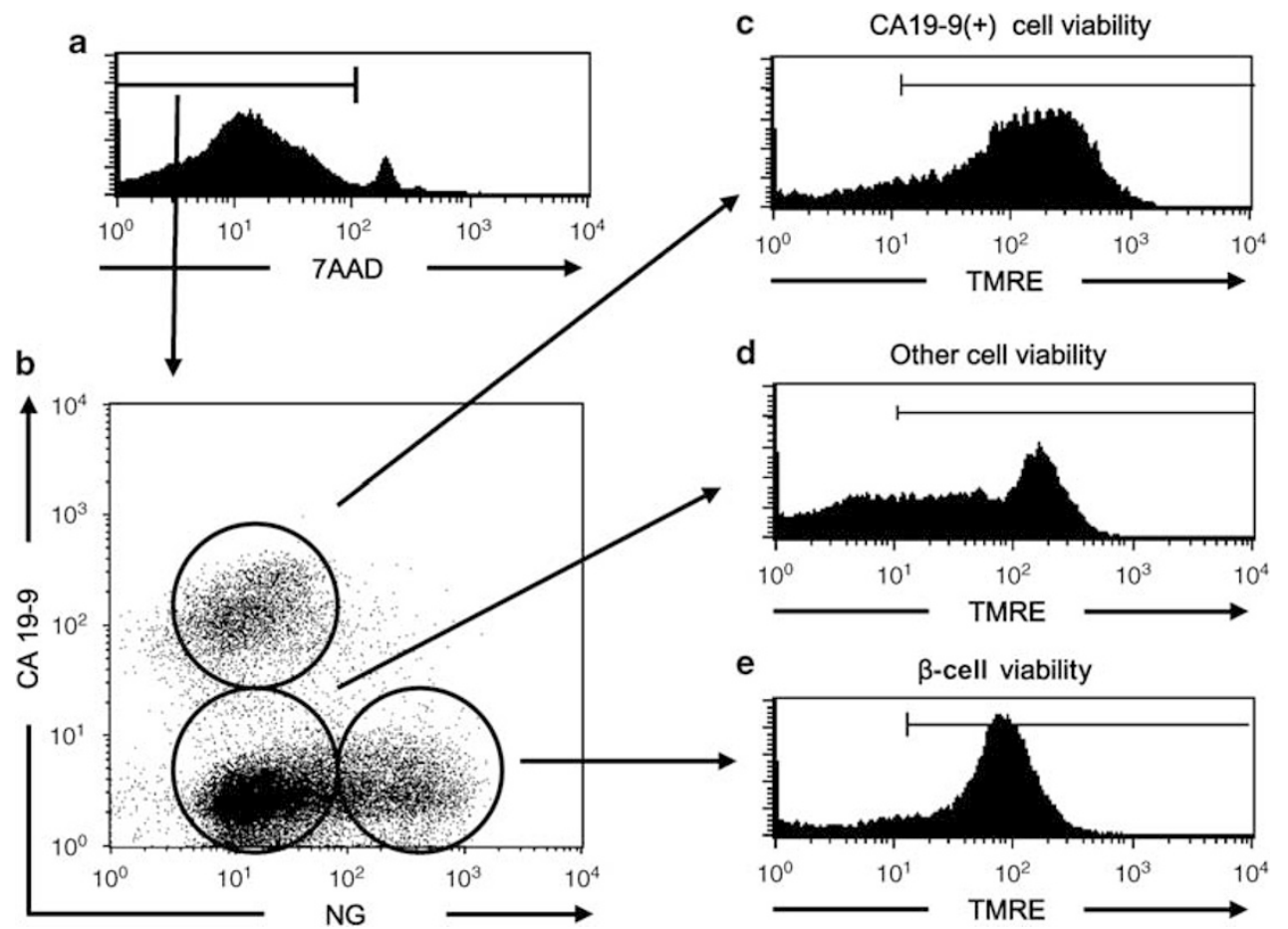

Figure 4 Simultaneous assessment of $\beta$-cell and PDC viability by FACS. Schematics of the analytical methodology utilized to assess simultaneous apoptosis of $\beta$-cells and PDC. After dissociation of human islets, single-cell suspensions were stained with 7-AAD, NG, CA19-9, and TMRE. The percentage of 7-AAD + cells (dead cells) is recorded (panel a), and further analysis is performed after their exclusion (gating out). The two subsets identified by NG and CA19-9

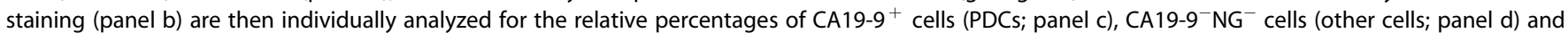
$\mathrm{NG}^{+}$cells ( $\beta$-cells; panel e) expressing $\mathrm{TMRE}^{+}$(viable cells) and $\mathrm{TMRE}^{-}$(apoptotic cells). 
a

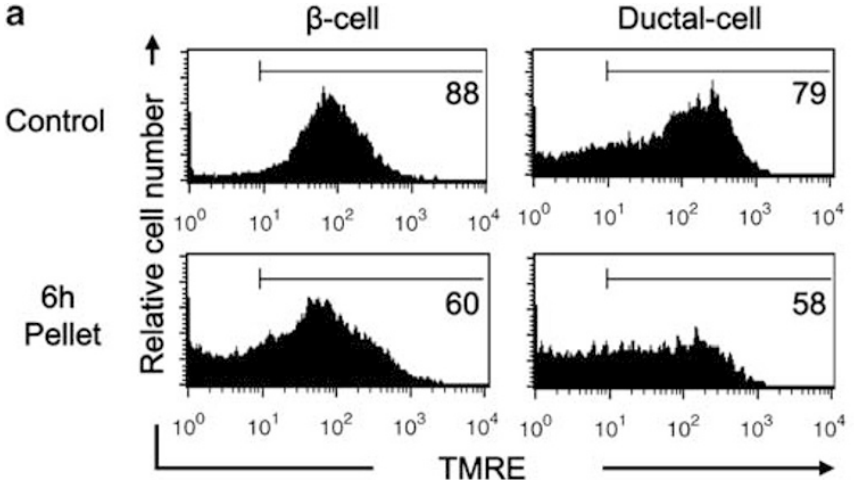

c

Control

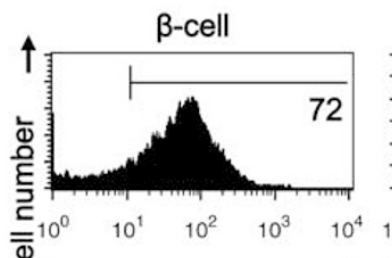

SNAP treated

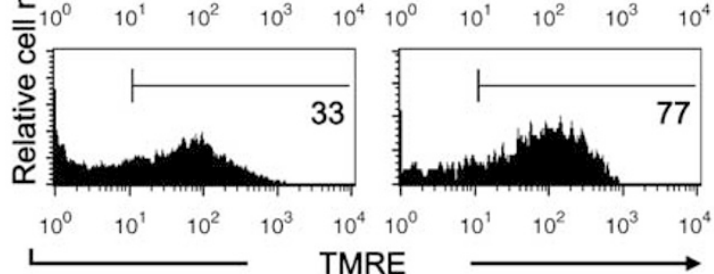

b

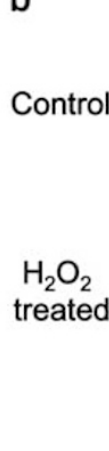

d

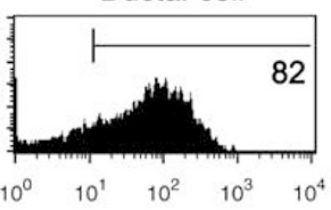

77

control
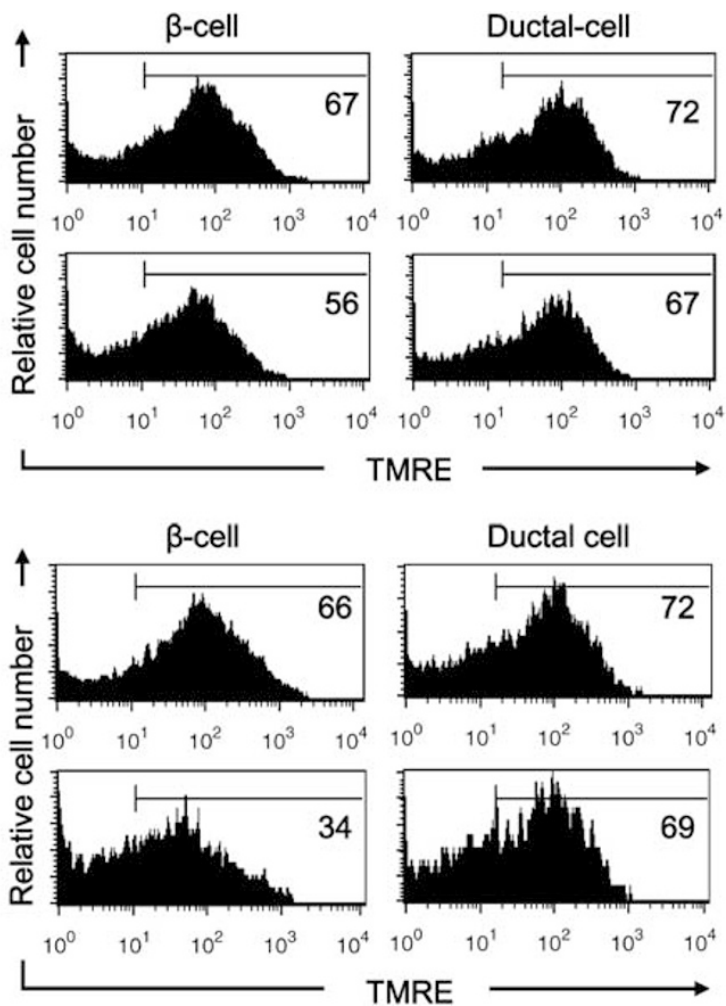

Figure 5 Analysis of $\beta$-cells and PDC apoptosis after delivery of noxious stimuli. Islet preparations were incubated in the presence or absence of noxious stimuli before assessment of viability in dissociated cells. Islet cell viability following hypoxic/starving conditions (compaction of islet preparations; panel a), $\mathrm{H}_{2} \mathrm{O}_{2}$ (panel b), nitric oxide donor SNAP (panel c), and cytokine cocktail (IL1- $\beta$, TNF- $\alpha$ and IFN- $\gamma$; panel d). Apoptosis was analyzed by TMRE staining in the $\beta$-cell and PDC subsets. Incubation of islet cells in any of the four conditions resulted in increased apoptosis in both $\beta$-cells and PDC populations, suggesting a selective proapoptotic effect of the studied compounds on both cell subsets. Additionally, these results showed that PDCs were more resistant to the noxious conditions, such as $\mathrm{H}_{2} \mathrm{O}_{2}$, NO and cytokines, than $\beta$-cells. Data are representative of at least five independent experiments.

(anti-CA19-9) provides precise and objective information on the viability and content of PDC as well as of $\beta$-cells. Our results showed that the content and viability of PDC in islet preparations extensively differed, and that PDC from highdensity fractions produced higher amount of proinflammatory cytokine/chemokines and VEGF but lower TF when compared to low-density fractions. Our data suggest that the precise assessment of PDC in addition to $\beta$-cells in human islet cell products may be of assistance in developing strategies to enhance islet graft function.

Although the clinical outcomes of islet transplantation have significantly improved, ${ }^{1-4}$ almost $90 \%$ of the recipients in recent trials required reintroduction of insulin within 5 years. ${ }^{5,6}$ This currently limited success provides impetus for assessing possible reasons for such an outcome, and trying to make changes that can allow for long-term graft function. Multiple factors may have contributed to the limited function of transplanted islets in the clinical setting. It is conceivable that a reduction of islet cell regeneration potential may have occurred due to the adverse effect of immunosuppressive drugs, ${ }^{27,30}$ the place of implantation (eg, liver, which may be unsuitable for regeneration) or/and the loss of $\beta$-cell precursors in islet preparations.
Insulin-secreting cells have been obtained in vitro from diverse sources, including embryonic stem cells. ${ }^{31,32}$ Several studies suggest that somatic stem cells can give rise to insulin-producing cells, including hepatic oval cells, ${ }^{33}$ spleenderived cells ${ }^{34}$ and marrow-derived cells. ${ }^{35}$ PDC are closely associated with $\beta$-cells in the human pancreas ${ }^{36}$ and have been shown to give rise to endocrine cells in both rodents and humans. ${ }^{10-12}$ Beneficial effects of PDC on islet cell viability have been described, which may be partially attributed to their ability of producing IGF-II. ${ }^{14,15}$ On the other hand, PDC may have detrimental effects on islet engraftment and survival. Exposure of PDC to IL- $1 \beta$ and interferon- $\gamma$ (IFN- $\gamma$ ) can result in NO production in human islets infiltrated by cytokine-releasing immune cells. ${ }^{18}$ Moreover, contaminating PDC may contribute to early $\beta$-cell damage after intrahepatic islet transplantation through their expression of TF. ${ }^{19,28,29}$ Immunogenicity of PDC may also relate to the expression of CD40, a member of the TNF-receptor family that was initially described in B cells, activated monocytes, dendritic, endothelial and epithelial cells as well as fibroblasts. ${ }^{37,38}$ Moreover, we recently found that purified pancreatic $\beta$-cells express a functional CD40 and that, following engagement with its ligand (CD154) results in the secretion of proin- 
a

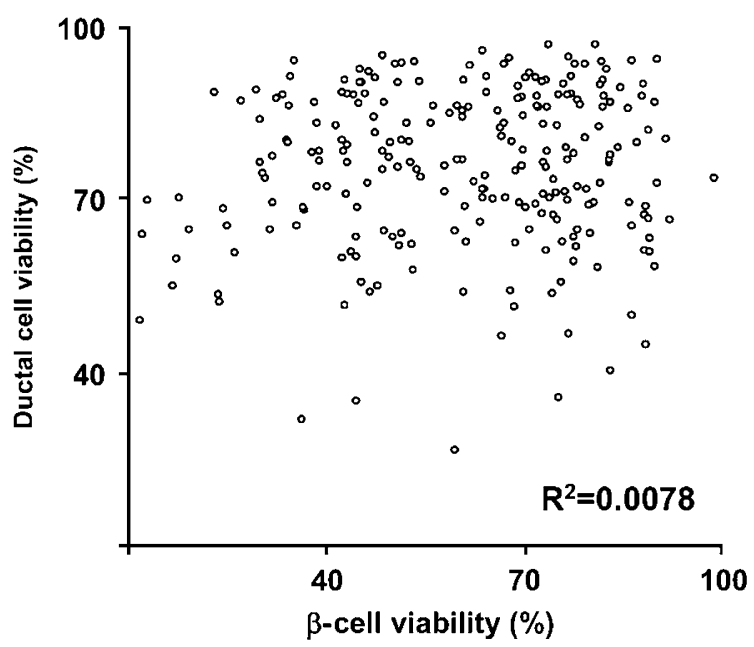

c

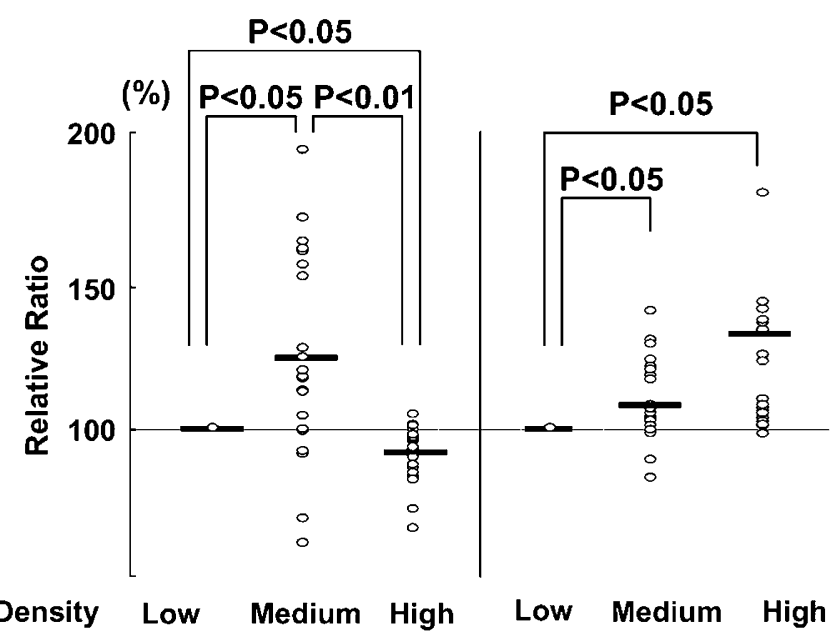

$\beta$-cell

Ductal cell b

Low density

Medium density

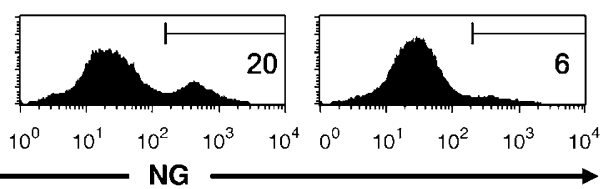

Ductal cell content

$\beta$-cell

viability

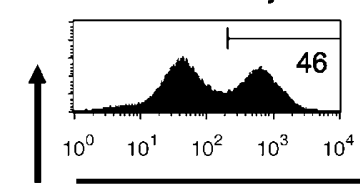

$\beta$-cell content
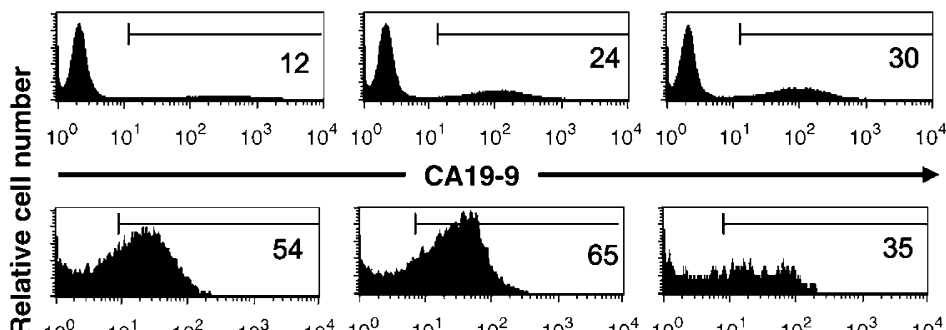

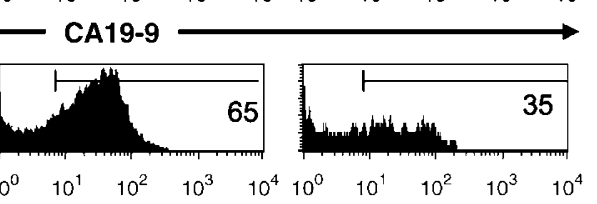

TMRE

68
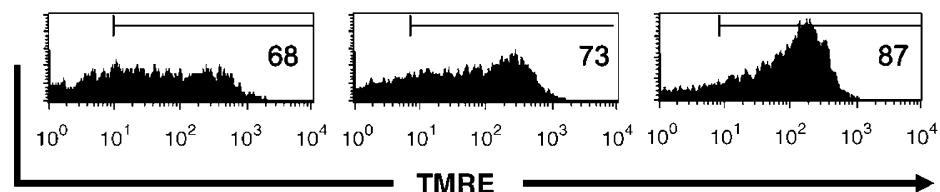

Figure 6 Analysis of $\beta$-cell and PDC-specific viability/apoptosis in islet fractions with different densities. (a) The analysis of 202 islet fractions showed no correlation between $\beta$ - and PDC-specific viability. (b) Representative data comparing three islet cell fractions with different degrees of purity collected from layers with increasing density: after gating the $7 \mathrm{AAD}^{-}$cell population, the percentages of $\mathrm{TMRE}^{+}$cells in NG ${ }^{\text {bright }}$ ( $\beta$-cells) or CA19-9 ${ }^{+}$cells (PDCs) were analyzed. (c) Islet aliquots with different degrees of purity collected from high, medium and low-density layers were assessed by FACS. Although $\beta$-cell viability in medium- and high-density fractions were significantly high and low when compared to low density fractions, the increase of PDC viability was observed as the density of fraction increased (lower purity).

flammatory mediators including IL-6, IL-8, MCP-1 and MIP-1 $\beta .^{39,40}$ The CD40-CD154 costimulation pathway plays a pivotal role in numerous T-cell-mediated inflammatory disorders. ${ }^{36-38,41}$

Korbutt et al showed that the number of $\mathrm{CK}_{1} 9^{+}$cells in islet preparations correlated well with the long-term metabolic success of clinical islet transplantation. ${ }^{16}$ This phenomenon may result from a greater frequency of islet cell neogenesis from putative PDC precursors. Additionally, Pipeleer et al have shown that PDC might be a source of IL-8 and VEGF, which may be beneficial for the revascularization of islets after implantation. ${ }^{17}$ Human islet grafts include a sizable mass of nonendocrine tissue that is transplanted with endocrine cells, and that may contribute to the early and long-term outcome. ${ }^{4,5}$ Rodent studies also suggest that the composition of islet grafts, including endocrine and nonendocrine cell subsets, may influence long-term metabolic function. ${ }^{18,19}$

Before this study, there was no assessment method for the detailed characterization of PDC content and viability. 


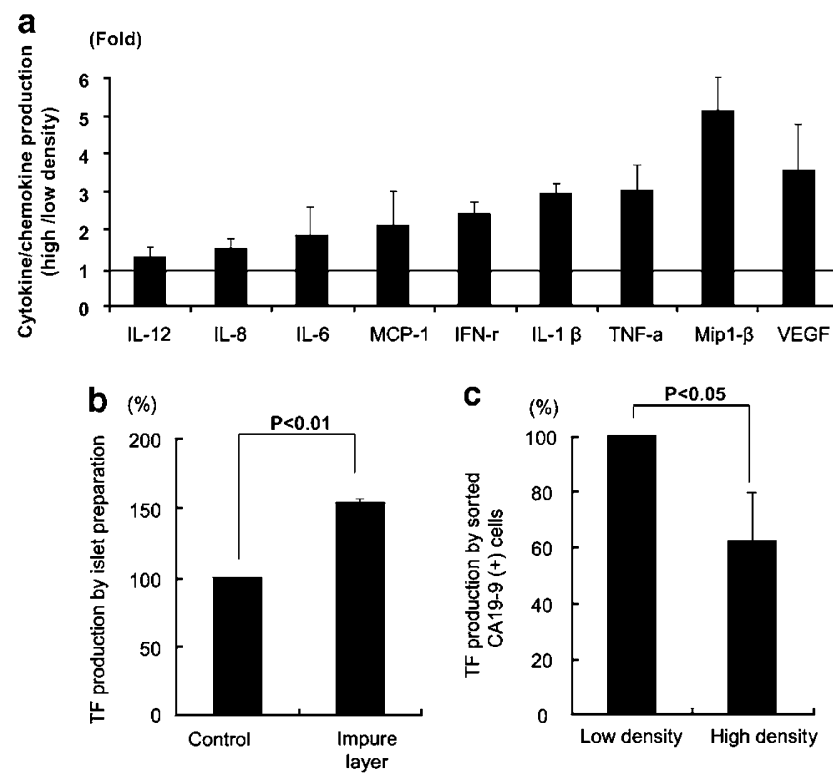

Figure 7 Functional analysis of PDCs obtained from different density fractions. To evaluate the function of PDCs from low- or high-density purification fractions of the same human islet preparation, PDCs were sorted using anti-CA19-9 antibody. The sorted PDCs were cultured for $24 \mathrm{~h}$ before collection of supernatant and of the cells for the measurement of cytokine/chemokine, VEGF and TF production, respectively. (a) Cytokine/ chemokine and VEGF production in the PDCs sorted from high density were higher than that of low-density fractions. (b) Impure islet fraction from heavier the layer produced significantly higher amount of TF. (c) A significant reduction in terms of TF production was observed in PDCs sorted from the high-density fraction, when compared to low density fractions. Data are representative of four independent human islet cell preparation.

Analysis of nonendocrine cells through LSC/iCys revealed that a substantial amount of $\mathrm{Amy}^{+}$cells also expressed CK19, suggesting that a single staining with CK19 could lead to an overestimation of PDC numbers by also counting acinar cell subsets. Moreover, it appears difficult by means of conventional immunohistochemical techniques to distinguish CK $19^{\text {bright }}$ from CK19 $9^{\text {dull }}$ cells, which are mainly composed of $\alpha$-cells and $\delta$-cells. ${ }^{16}$ Conversely, the analysis performed by LSC/iCys allowed for an objective and detailed phenotypic analysis of higher numbers of cells in a relatively short time. Moreover, PDC viability might represent a critical variable for both inflammation and regenerative potential after transplantation. Our data indicate that there was wide variability regarding PDC viability based on the analysis of more than 200 human islet fractions. Interestingly, we observed that PDC with higher viability were obtained from high-density fractions (lower purity). In addition, higher cytokine/chemokine and VEGF levels were obtained from more viable PDC.

The need for reliable predictive islet cell product tests has prompted the development of multiple potency assays such as oxygen consumption rate, ${ }^{42-44}$ analysis of ATP levels ${ }^{45}$ and the measurement of ROS. ${ }^{46}$ All proposed methods have shown promise regarding their predictive value on graft
Table 1 Cytokine/chemokine and VEGF production in ductal cells sorted from low- or high-density layer

\begin{tabular}{lccc}
\hline & $\begin{array}{c}\text { Low-density layer } \\
(\mathrm{pg} / \mathrm{ml})\end{array}$ & $\begin{array}{c}\text { High-density layer } \\
(\mathrm{pg} / \mathrm{ml})\end{array}$ & $\begin{array}{c}\text { High/low } \\
\text { fold }\end{array}$ \\
\hline IL-12 & $16.8 \pm 9.8$ & $21.5 \pm 8.6$ & 1.28 \\
IL-8 & $92320.0 \pm 21031.5$ & $139788.2 \pm 45721.8$ & 1.51 \\
IL-6 & $37021.5 \pm 20586.6$ & $69247.3 \pm 36692.0$ & 1.87 \\
MCP-1 & $54068.3 \pm 22861.6$ & $114258.7 \pm 17140.9$ & 2.11 \\
IFN- $\gamma$ & $152.0 \pm 50.2$ & $366.5 \pm 101.8$ & 2.41 \\
IL-1 $\beta$ & $561.8 \pm 684.2$ & $1664.4 \pm 3183.6$ & 2.96 \\
TNF- $\alpha$ & $281.0 \pm 126.2$ & $853.3 \pm 266.8$ & 3.04 \\
Mip1- $\beta$ & $1284.7 \pm 654.0$ & $6639 \pm 3501.2$ & 5.17 \\
VEGF & $19090.2 \pm 6647.4$ & $67867.3 \pm 15441.0$ & 3.55 \\
\hline
\end{tabular}

function into chemically diabetic, immunodeficient mice receiving high purity human or porcine islets (the latter generally $\sim 80-90 \% \beta$-cell content). However, clinical islet preparations are composed not only of $\beta$-cells, but also by a substantial amount of nonendocrine and endocrine $(\alpha$ - and $\delta$-cells) cellular subsets. The most difficult part in islet potency testing is to identify $\beta$-cell-specific contribution to the results obtained in each of these tests. Notably, for potency assays that do not discriminate for cell subsets, only if each cell subset within the same islet preparation has similar viability, the result of the test may be representative to $\beta$-cell viability. According to the analysis of more than 160 islet preparations in our study, the viability and content of PDC and of $\beta$-cells widely varied and there was no correlation between PDC and $\beta$-cell values. These results clearly indicate that the assessment of heterogeneous cell populations such as ADP/ATP ratio and FDA/PI cannot represent $\beta$-cell-specific viability.

Another critical issue to be addressed in islet potency testing is whether the viability of islet aliquots obtained from the purest layers can safely represent that of an entire final islet preparation with lower purity. Our data showed that $\beta$-cell viability in medium- and high-density fractions was significantly higher and lower, respectively. In addition, high-density fractions showed the highest PDC viability, which decreased linearly in lower density fractions. These results indicate that the viability assessment of the purest islet fractions may not reflect adequately that of PDC or $\beta$-cells in whole islet preparations, and that the sample for islet quality assessment and $\beta$-cell viability should be obtained from a mixed fraction of the final islet cell product after mixing pure and impure fractions. Therefore, some islet quality tests evaluating whole islet cells (ie, FDA/PI and ADP/ATP ratio) may overestimate $\beta$-cell viability due to the contribution to the readout of PDC with higher viability composing the final preparation. 

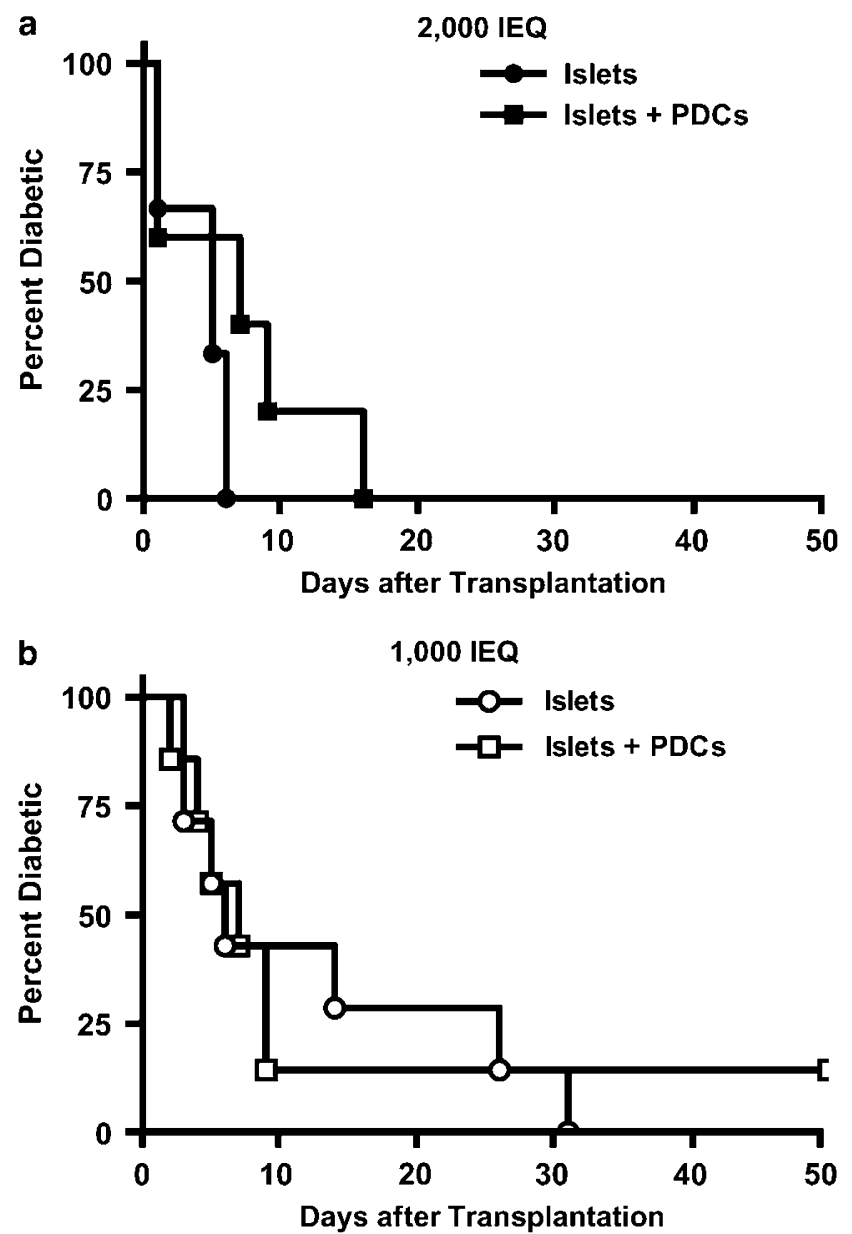

Figure 8 In vivo assessment of islet potency. Human islets were implanted with or without sorted PDCs under the kidney capsule of chemically induced diabetic nude mice. Two masses of islets were implanted: 2000 IEQ (a) and 1000 IEQ (b) alone (circles) or together with sorted $3 \times 10^{6}$ PDCs (squares). The proportion of diabetic animals after islet transplantation was plotted for the experimental groups: Islets alone (2000 IEQ/mouse; $n=6$; -); Islets (2000 IEQ/mouse) + PDCs $\left(3 \times 10^{6} ; n=5 ; \mathbf{\square}\right)$; Islets alone (1000 $\mathrm{IEQ} /$ mouse; $n=7 ; \bigcirc)$ and Islets (1000 IEQ/mouse) + PDCs $\left(3 \times 10^{6} ; n=7\right.$; $\square)$. Nephrectomy of the graft-bearing kidney performed 50 days after implant resulted in prompt return to hyperglycemia (not shown). Data are representative of three independent human islet preparations.

Although it is apparent that islet cell quality is critical for clinical outcomes, other factors such as inflammation mediators, VEGF and TF should be taken into account for overall assessment of islet cell products. Indeed, MCP-1 secreted by islet preparations may negatively affect the clinical outcomes $^{47,48}$ and TF may trigger detrimental thrombotic reactions at the time of intrahepatic islet infusion. ${ }^{28}$ However, VEGF and IL- 8 may be beneficial for revascularization in islet grafts. In our study, we observed that PDC secrete proinflammatory cytokines/chemokines that PDC may have either beneficial or detrimental effects on islet viability and function. In the in vivo bioassay model, cotransplantation of PDC did not alter graft outcomes in our study. There was no measurable improvement of islet engraftment, despite an increased VEGF and IL-8 secretion from PDC in vitro that might have been beneficial. Notably, this immunodeficient murine model does not allow mimicking the complex immune phenomena ongoing in the setting of islet transplantation into patients with autoimmune diabetes. It is conceivable that lymphocytes and monocytes infiltrating islet grafts may be activated/recruited by cytokines/chemokines produced by PDC. Future efforts will focus on the effects of PDC on the function of islet grafts in clinical islet transplantation.

In summary, we have established a novel method for the simultaneous assessment of PDC and $\beta$-cell content and viability in human islet preparations. The precise assessment of nonendocrine cells in addition to $\beta$-cells in human islet cell products may be of assistance in developing strategies to enhance islet graft function.

\section{ACKNOWLEDGEMENTS}

This work was supported in part by National Institutes of Health grants for General Clinical Research Center (5U01DK70460-02, 5R01DK025802-23), Islet Cell Resources (5U42RR016603), Juvenile Diabetes Research Foundation International (4-2004-361), and the Diabetes Research Institute Foundation (http://www.DiabetesResearch.org). We are grateful to the members of the Human Cell Processing Facility, Preclinical Cell Processing Laboratory of the Cell Transplant Center, Clinical Islet Transplant Program, General Clinical Research Center, Imaging Core at the Diabetes Research Institute, Administrative Offices at the Diabetes Research Institute and Organ Procurement Organizations for the continuous enthusiasm and support to our program.

1. Shapiro AM, Lakey JR, Ryan EA, et al. Islet transplantation in seven patients with type 1 diabetes mellitus using a glucocorticoid-free immunosuppressive regimen. N Engl J Med 2000;343:230-238.

2. Markmann JF, Deng $S$, Huang $X$, et al. Insulin independence following isolated islet transplantation and single islet infusions. Ann Surg 2003;237:741-749.

3. Hering BJ, Kandaswamy R, Harmon JV, et al. Transplantation of cultured islets from two-layer preserved pancreases in type 1 diabetes with anti-CD3 antibody. Am J Transplant 2004;4:390-401.

4. Froud $T$, Ricordi $C$, Baidal DA, et al. Islet transplantation in type 1 diabetes mellitus using cultured islets and steroid-free immunosuppression: Miami experience. Am J Transplant 2005;5: 2037-2046.

5. Shapiro AM, Ricordi C, Hering BJ, et al. International trial of the Edmonton protocol for islet transplantation. N Engl J Med 2006:355:1318-1330.

6. Ryan EA, Paty BW, Senior PA, et al. Five-year follow-up after clinical islet transplantation. Diabetes 2005;54:2060-2069.

7. Zhang N, Su D, Qu S, et al. Sirolimus is associated with reduced islet engraftment and impaired beta-cell function. Diabetes 2006;55: 2429-2436.

8. Bussiere CT, Lakey JR, Shapiro AM, et al. The impact of the mTOR inhibitor sirolimus on the proliferation and function of pancreatic islets and ductal cells. Diabetologia 2006;49:2341-2349.

9. Holland AM, Gonez L, Harrison LC, et al. Progenitor cells in the adult pancreas. Diabetes Metab Res Rev 2004;20:13-27.

10. Yatoh S, Dodge R, Akashi T, et al. Differentiation of affinity-purified human pancreatic duct cells to beta-cells. Diabetes 2007;56:18021809.

11. Ramiya VK, Maraist M, Arfors KE, et al. Reversal of insulin-dependent diabetes using islets generated in vitro from pancreatic stem cells. Nat Med 2000;6:278-282.

12. Bonner-Weir S, Taneja M, Weir GC, et al. In vitro cultivation of human islets from expanded ductal tissue. Proc Natl Acad Sci USA 2000;97:7999-8004. 
13. Gao R, Ustinov J, Pulkkinen MA, et al. Characterization of endocrine progenitor cells and critical factors for their differentiation in human adult pancreatic cell culture. Diabetes 2003;52:2007-2015.

14. Ilieva A, Yuan S, Wang RN, et al. Pancreatic islet cell survival following islet isolation: the role of cellular interactions in the pancreas. J Endocrinol 1999;161:357-364.

15. Robitaille R, Dusseault J, Henley N, et al. Insulin-like growth factor II allows prolonged blood glucose normalization with a reduced islet cell mass transplantation. Endocrinology 2003;144:3037-3045.

16. Street CN, Lakey JR, Shapiro AM, et al. Islet graft assessment in the Edmonton Protocol: implications for predicting long-term clinical outcome. Diabetes 2004;53:3107-3114.

17. Movahedi B, Gysemans C, Jacobs-Tulleneers-Thevissen D, et al. Pancreatic duct cells in human islet-cell preparations are a source of angiogenic cytokines IL-8 and VEGF. Diabetes 2008;57:2128-2136.

18. Pavlovic D, Chen MC, Bouwens $L$, et al. Contribution of ductal cells to cytokine responses by human pancreatic islets. Diabetes 1999;48: 29-33.

19. Beuneu C, Vosters O, Movahedi B, et al. Human pancreatic duct cells exert tissue factor-dependent procoagulant activity: relevance to islet transplantation. Diabetes 2004;53:1407-1411.

20. Latif ZA, Noel J, Alejandro R. A simple method of staining fresh and cultured islets. Transplantation 1988;45:827-830.

21. Kuroda $Y$, Kawamura T, Suzuki $Y$, et al. A new, simple method for cold storage of the pancreas using perfluorochemical. Transplantation 1988;46:457-460.

22. Ricordi C, Lacy PE, Finke EH, et al. Automated method for isolation of human pancreatic islets. Diabetes 1988;37:413-420.

23. Ichii $\mathrm{H}$, Pileggi $\mathrm{A}$, Molano RD, et al. Rescue purification maximizes the use of human islet preparations for transplantation. Am J Transplant 2005;5:21-30.

24. Ichii $H$, Inverardi L, Pileggi $A$, et al. A novel method for the assessment of cellular composition and beta-cell viability in human islet preparations. Am J Transplant 2005;5:1635-1645.

25. Ichii $\mathrm{H}$, Wang $\mathrm{X}$, Messinger $\mathrm{S}$, et al. Improved human islet isolation using nicotinamide. Am J Transplant 2006;6:2060-2068.

26. Gmyr V, Belaich S, Muharram G, et al. Rapid purification of human ductal cells from human pancreatic fractions with surface antibody CA19-9. Biochem Biophys Res Commun 2004;320:27-33.

27. Cantaluppi V, Biancone L, Romanazzi GM, et al. Antiangiogenic and immunomodulatory effects of rapamycin on islet endothelium: relevance for islet transplantation. Am J Transplant 2006;6: 2601-2611.

28. Moberg $\mathrm{L}$, Johansson $\mathrm{H}$, Lukinius $\mathrm{A}$, et al. Production of tissue factor by pancreatic islet cells as a trigger of detrimental thrombotic reactions in clinical islet transplantation. Lancet 2002;360:2039-2045.

29. Johansson $H$, Lukinius $A$, Moberg $L$, et al. Tissue factor produced by the endocrine cells of the islets of Langerhans is associated with a negative outcome of clinical islet transplantation. Diabetes 2005;54:1755-1762

30. Gao R, Ustinov J, Korsgren O, et al. Effects of immunosuppressive drugs on in vitro neogenesis of human islets: mycophenolate mofetil inhibits the proliferation of ductal cells. Am J Transplant 2007;7:1021-1026.
31. Soria B, Roche $E$, Berna $G$, et al. Insulin-secreting cells derived from embryonic stem cells normalize glycemia in streptozotocin induced diabetic mice. Diabetes 2000;49:157-162.

32. Lumelsky N, Blondel $\mathrm{O}$, Laeng $\mathrm{P}$, et al. Differentiation of embryonic stem cells to insulin-secreting structures similar to pancreatic islets. Science 2001;292:1389-1394.

33. Yang $\mathrm{L}$, Li S, Hatch $\mathrm{H}$, et al. In vitro trans-differentiation of adult hepatic stem cells into pancreatic endocrine hormone-producing cells. Proc Natl Acad Sci USA 2002;99:8078-8083.

34. Kodama S, Kuhtreiber W, Fujimura S, et al. Islet regeneration during the reversal of autoimmune diabetes in NOD mice. Science 2003;302:1223-1227.

35. lanus A, Holz GG, Theise ND, et al. In vivo derivation of glucosecompetent pancreatic endocrine cells from bone marrow without evidence of cell fusion. J Clin Invest 2003;111:843-850.

36. Bouwens L, Pipeleers DG. Extra-insular beta cells associated with ductules are frequent in adult human pancreas. Diabetologia 1998:41:629-633.

37. van Kooten C, Banchereau J. CD40-CD40 ligand. J Leukoc Biol 2000;67:2-17.

38. van Kooten C, Banchereau J. Functions of CD40 on B cells, dendritic cells and other cells. Curr Opin Immunol 1997;9:330-337.

39. Klein D, Barbe-Tuana F, Pugliese A, et al. A functional CD40 receptor is expressed in pancreatic beta cells. Diabetologia 2005;48:268-276.

40. Barbe-Tuana FM, Klein D, Ichii $\mathrm{H}$, et al. CD40-CD40 ligand interaction activates proinflammatory pathways in pancreatic islets. Diabetes 2006;55:2437-2445.

41. Grewal IS, Flavell RA. CD40 and CD154 in cell-mediated immunity. Annu Rev Immunol 1998;16:111-135.

42. Fraker C, Timmins MR, Guarino RD, et al. The use of the BD oxygen biosensor system to assess isolated human islets of langerhans: oxygen consumption as a potential measure of islet potency. Cell Transplant 2006;15:745-758.

43. Papas KK, Colton CK, Nelson RA, et al. Human islet oxygen consumption rate and DNA measurements predict diabetes reversal in nude mice. Am J Transplant 2007;7:707-713.

44. Wang W, Upshaw L, Strong DM, et al. Increased oxygen consumption rates in response to high glucose detected by a novel oxygen biosensor system in non-human primate and human islets. J Endocrinol 2005;185:445-455.

45. Goto $M$, Holgersson J, Kumagai-Braesch $M$, et al. The ADP/ATP ratio: a novel predictive assay for quality assessment of isolated pancreatic islets. Am J Transplant 2006;6:2483-2487.

46. Armann B, Hanson MS, Hatch E, et al. Quantification of basal and stimulated ROS levels as predictors of islet potency and function. Am J Transplant 2007;7:38-47.

47. Piemonti $L$, Leone $B E$, Nano $R$, et al. Human pancreatic islets produce and secrete MCP-1/CCL2: relevance in human islet transplantation. Diabetes 2002;51:55-65.

48. Bertuzzi F, Marzorati S, Maffi $P$, et al. Tissue factor and CCL2/monocyte chemoattractant protein-1 released by human islets affect islet engraftment in type 1 diabetic recipients. J Clin Endocrinol Metab 2004;89:5724-5728. 